\title{
A fotografia para além do registro histórico: o trabalho social, pedagógico e artístico de Tina Modotti nas "Escuelas Libres de Agricultura"
}

Fabiane Tais Muzardo*

\section{RESUMO}

A década de 1920 no México foi marcada por intensa produção cultural. Tina Modotti e outros artistas das mais variadas áreas iniciaram um projeto que visava produzir uma arte que fosse pública, ou seja, que fosse feita pelo povo e para o povo. Nesse sentido, a arte mexicana dessa década é marcadamente política. Tina foi uma fotógrafa italiana que se mudou para o México no início dos anos 1920. Seu trabalho inclui fotografias de murais, camponeses, símbolos comunistas, manifestaçóes de trabalhadores, plantas, arquitetura, caveiras e escolas agrícolas, dentre outras temáticas. Suas fotografias foram publicadas em inúmeros periódicos, desde revistas de arte até atas de criação dessas escolas. Este artigo analisa as fotografias de Tina que compóem as atas de criação e desenvolvimento das escolas agrícolas, entendendo-as como uma produção que possui, ao mesmo tempo, um sentido social, pedagógico e artístico.

Palavras-chave: Tina Modotti; fotografia; México; arte; política.

\section{Photographs for more than the historical record: the social, pedagogical and artistic work of Tina Modotti in the "Escuelas Libres de Agricultura"}

\section{ABSTRACT}

During the 1920s in Mexico, there was intense culture production that was markedly political. Tina Modotti and others artists from different areas began producing art that was public, meaning art made by people and for the people. Tina was an Italian photographer who moved to Mexico in the early 1920s. His portfolio includes photographs of murals, 
A FOTOGRAFIA PARA ALÉM DO REGISTRO HISTÓRICO: O TRABALHO SOCIAL, PEDAGÓGICO E ARTÍSTICO DE Tina Modotti nas "Escuelas Libres de Agricultura"

Fabiane Taís Muzardo

peasants, communist symbols, worker strikes and protests, plants, architecture, skulls, and agricultural schools, among other themes. His photographs were featured in countless publications, from art magazines to the promotional documents and circulars of new agricultural schools, which shows that the photographs had social and pedagogical meaning in addition to their artistic merits.

Keywords: Tina Modotti; photography; Mexico; art; politics.

\section{La fotografía más allá del registro histórico: el trabajo social, pedagógico y artístico de Tina Modotti en las "Escuelas Libres de Agricultura"}

\section{RESUMEN}

La década de 1920 en México fue marcada por una intensa producción cultural. Tina Modotti y otros artistas de las más variadas áreas iniciaron un proyecto que pretendía producir un arte que fuese público, es decir que fuese hecho por el pueblo y para el pueblo. En este sentido, el arte mexicano de esta década es marcadamente político. Tina fue una fotógrafa italiana que se mudó a México a inicios de los años veinte. Su trabajo incluye fotografías de murales, campesinos, símbolos comunistas, manifestaciones de trabajadores, plantas, arquitectura, calaveras y escuelas agrícolas, entre otras temáticas. Sus fotografías fueron publicadas en innúmeros periódicos, desde revistas de arte hasta actas de creación de esas escuelas. Este artículo analiza las fotografías de Tina que componen las actas de creación y desarrollo de las escuelas agrícolas, entendiéndolas como una producción que posee, al mismo tiempo, un sentido social, pedagógico y artístico.

Palabras clave: Tina Modotti; fotografia; México; arte; política.

Tina Modotti nasceu em Udine, na Itália, no ano de 1896, numa família de trabalhadores humildes com forte ativismo político. Segundo Margareth Hooks, não se sabe ao certo se Giuseppe Modotti, pai de Tina, era membro do "Círculo Socialista" de Udine. Apesar disso, Tina e suas irmãs, anos mais tarde, teriam afirmado "que seu pai fora um 'socialista' e um firme defensor das causas sindicalistas" (HOOKS, 1997, p. 20). Em 1906, Giuseppe Modotti se mudou para os Estados Unidos da América com o objetivo de juntar dinheiro suficiente para que toda a família pudesse viver na América. Foi assim que, em 1913, Tina se juntou ao pai nos EUA, onde viveu por aproximadamente uma década, até se mudar para o México. Nos Estados Unidos, Tina trabalhou como costureira em uma fábrica. Esse fato também pode ter colaborado para a militância de Tina e sua visão a respeito do trabalho e da desigualdade social. Esse percurso de Tina em solo americano foi marcado por uma série 
A FOTOGRAFIA PARA ALÉM DO REgISTRO HISTÓRICO: O TRABALHO SOCIAL, PEDAGÓGICO E ARTÍSTICO DE Tina Modotti nas "Escuelas Libres de Agricultura"

Fabiane Taís Muzardo

de encontros. Em 1915, Tina teve seu primeiro contato com o trabalho de Edward Weston, o que acabaria lhe gerando novas possibilidades, pessoais e profissionais. No início dos anos 1920 conheceu a escritora, antropóloga, tradutora e editora de livros mexicana Anita Brenner, que, logo depois, convidou-a para fazer parte do projeto que resultou na publicação de Idolos tras los altares ${ }^{1}$. Seu relacionamento com pessoas como o militante e artista Xavier Guerrero, o indiano Pandurang Kankhoje, responsável pela criação e aperfeiçoamento das escolas agrícolas camponesas; e o militante comunista Julio Antonio Mella, abriu possibilidades para que Tina se aproximasse dos pintores muralistas, da produção de importantes publicaçóes, como El Machete ${ }^{2}$; do Partido Comunista Mexicano (PCM), dos camponeses etc.

Tina se mudou para o México no ano de 1922. Edward Weston, naquele momento um fotógrafo já renomado, a acompanhou. Foi no México que Tina começou a fotografar, inicialmente sob a tutela de Weston. A fotografia, todavia, fazia parte de sua vida desde muito tempo, desde a infância e a convivência com Pietro Modotti, seu tio fotógrafo. Todavia, Tina somente fotografou no México. Quando foi deportada ${ }^{3}$, em 1930, devido a perseguiçóes políticas, Tina parou de fotografar.

No México, Tina foi convidada a participar de diversos projetos, que incluíam desde revistas de arte até o registro de criação e atividades de escolas agrícolas. Suas fotografias, portanto, possuem diversas temáticas: máscaras, sombreros, mulheres, camponeses, murais, escolas etc. Suas imagens foram pensadas para e publicadas em diversos meios. Um dos primeiros trabalhos que realizou em solo mexicano foi o de produzir fotografias, junto com

\footnotetext{
${ }^{1}$ Estruturalmente, o livro de Anita Brenner divide-se em três partes, a partir de uma abordagem cronológica: México pré-hispânico, colonial e moderno. Em cada uma das partes a autora mescla crônicas populares, resultados de sua observação, descobertas e suas próprias lembranças. Na introdução, Brenner apresenta a metodologia escolhida, esclarecendo se tratar de um livro que parte de uma perspectiva antropológica, náo sendo, portanto, nem um livro de crítica nem de história da arte. Idolos... foi publicado pela primeira vez no ano de 1929, nos Estados Unidos, pela editora Payson \& Clarke. O livro teve várias edições em inglês. No México, o livro foi publicado uma única vez, em 1983, pela Editorial Domés S.A.

${ }^{2}$ El Machete foi o principal periódico comunista publicado no México nas décadas de 1920 e 1930 . O PCM foi o segundo a ser fundado na América, em 1919, logo após o término da fase armada da Revolução Mexicana. El Machete, a partir de 1925, tornou-se periódico oficial do PCM. O Centro de Estudios del Movimiento Obrero y Socialista (CEMOS), localizado na Cidade do México, possui, digitalizado, todo o acervo desse periódico.

${ }^{3}$ Em 1929, em meio a perseguiçóes políticas aos integrantes do PCM, que resultaram, inclusive, no fechamento de El Machete, Tina foi acusada de participar da tentativa de assassinato do presidente eleito Pascual Ortiz Rubio. Nessa ocasião, a vida pessoal de Tina foi utilizada para tentar validar essa acusação. Esse acontecimento, mais o artigo 33 da Constituição Mexicana resultaram em sua deportação. O artigo 33 "definia a las personas extranjeras por exclusión de las mexicanas y les otorgaba algunos derechos [...] y estabelecia que podían ser expulsadas por el Ejecutivo Federal sin Juicio prévio, al ser considerada unilateralmente por éste, como inconveniente su permanência en el país, previniéndoles además de no inmiscuirse de ningún modo en asuntos políticos del país, sin precisar mayor detalle al respecto". [Em tradução livre: "Definia as pessoas estrangeiras por exclusão das mexicanas e lhes outorgava alguns direitos [...] estabelecendo que podiam ser expulsas pelo Executivo Federal sem julgamento preliminar, ao serem consideradas inconvenientes no país, também os impedindo de participar de assuntos políticos no país, sem precisar maiores detalhes a esse respeito”] (DE DIENHEIM BARRIGUETE, 2013, p. 1.636).
} 
A FOTOGRAFIA PARA ALÉM DO REGISTRO HISTÓRICO: O TRABALHO SOCIAL, PEDAGÓGICO E ARTÍSTICO DE Tina Modotti nas "Escuelas Libres de Agricultura"

Fabiane Taís Muzardo

Edward Weston, para integrar o livro Idolos tras los altares, de Anita Brenner. Tina e Weston foram convidados por Brenner para viajar pelo território mexicano, conhecer comunidades e criar um discurso escrito e imagético sobre elas, no ano de 1923, ou seja, cerca de um ano após se mudarem para o México. Esse fato, ao nosso ver, comprova a intensidade do encontro de Tina com o México. Encontro esse que se tornou ainda mais potente com essa viagem e a convivência com pessoas e culturas tão diversas.

As "Escuelas Libres de Agricultura", objeto de análise desse texto, fizeram parte de um projeto nacional de desenvolvimento agrícola criado pelo governo mexicano na década de 1920 . Pandurang Khankhoje foi o responsável pela criação e expansão dessas escolas. As atividades desenvolvidas nelas, desde competiçóes entre os alunos para a escolha das melhores sementes até a forma de se desenvolver e os objetivos do ensino, foram registradas em atas durante os anos de 1927 e 1932. Quando retornou para a Índia, na década de 1950, Pandurang levou esses documentos consigo. Somente em 2014 esses documentos se tornaram públicos, quando a filha de Pandurang, Dra. Savitri Sawhney, doou toda a documentação produzida durante os anos em que seu pai residiu no México e trabalhou na criação e ampliação das escolas agrícolas. A doaçáo foi realizada junto ao Instituto Nacional de Antropologia e História do México e integra o acervo da Fototeca Nacional Mexicana, localizada em Pachuca.

Trata-se de um expediente das escolas Livres de Agricultura no México durante os anos vinte e trinta do século passado, onde as imagens de Tina Modotti se combinam com o texto impresso para constituir um documento de notável importância não só no campo da história da fotografia, mas da história do México (MARÍN, 2014, p. 5). ${ }^{4}$

O documento é composto por atas, ofícios, recortes de jornais e fotografias, totalizando 63 páginas. As páginas possuem furos do lado esquerdo, o que dá a entender que, quando da sua feição, elas foram organizadas de modo diferente ao que se encontram hoje em dia. As páginas iniciais receberam o carimbo da escola. As fotografias foram inseridas em páginas separadas do corpo do texto, por meio de encaixes nas folhas que as compóem, sendo acompanhadas por legendas datilografadas. Nossa análise da documentação foi definida a partir da participação de Tina no projeto, que se estendeu entre os anos de 1927 e 1928.

\footnotetext{
${ }^{4}$ Tradução livre. No original: "Se trata de un expediente de las escuelas Libres de Agricultura en Mexico durante los años veinte y treinta del siglo pasado, donde las imágenes de Tina Modotti se combinam con el texto impreso para constituir un documento de notable importância no sólo en el campo de la historia de la fotografia, sino de la historia de Mexico".
} 
A FOTOGRAFIA PARA ALÉM DO REGISTRO HISTÓRICO: O TRABALHO SOCIAL, PEDAGÓGICO E ARTÍSTICO DE Tina Modotti nas "Escuelas Libres de Agricultura"

Fabiane Taís Muzardo

\section{Pandurang Khankhoje e a criação das "Escuelas Libres de Agricultura”}

Pandurang Khankhoje nasceu em Waefha, na Índia, em 1886. Desde muito jovem, participou de lutas pela independência de seu país, o que fez com que fosse fichado pelas autoridades coloniais britânicas. Em 1906, devido a perseguições políticas, Pandurang se mudou para os Estados Unidos da América, onde viveu por quase duas décadas. Segundo Marín (2014), foi o interesse e admiração de Pandurang pela Revolução Mexicana, sua ideologia e seus participantes, que fez com que ele se mudasse para o México em 1924. É possível perceber certas semelhanças entre as trajetórias de Tina e Pandurang: desde cedo os dois tiveram forte posicionamento político; ainda jovens, saíram de seus países de origem e se mudaram para os Estados Unidos, e, principalmente, os dois sentiram-se atraídos pela cultura mexicana, um dos fatores que os fizeram se mudar para o México nos primeiros anos da década de 1920. Segundo Isabel Arline Duque, em algum momento, Khankhoje, "em tom de brincadeira, se reconheceria como 'duplamente índio"'s (DUQUE, 2014, p. 12).

No México, o primeiro trabalho de Pandurang foi na "Escuela Nacional de Agricultura". Essa escola, a princípio localizada no Distrito Federal, foi transferida para Chapingo durante um projeto de renovação dessa instituiçấo, que passou a se dirigir às "necessidades de repartição de terras, da criaçáo de novas variedades de sementes e plantas, do apoio a ejidatarios, entre muitas outras tarefas vinculadas aos planos agrários nacionais" (MASSÉ, 2014, p. 31). Percebe-se, desse modo, a atuação de um "Estado-mecenas" no México", visto que foi o governo mexicano que financiou as escolas de arte, a pintura mural e a criação das escolas agrícolas, dentre outros projetos, os quais, apesar da atuação de militantes comunistas declarados, como Tina, Rivera e Pandurang, sempre permaneceram sob tutela do Estado mexicano. Pode-se pensar, inclusive, que o fato de Tina ter sido convidada por Pandurang para integrar a equipe das escolas agrícolas reforça o aspecto de luta social que envolveu essas escolas desde seu projeto inicial, visto que Tina já era reconhecida, naquele momento, como uma fotógrafa voltada para as causas sociais. Vale ressaltar a função educativa das fotografias de Tina publicadas em diferentes periódicos, as quais possibilitaram desde uma disseminação dos murais produzidos nos prédios públicos até a produção de uma memória visual do PCM. A assinatura de Tina, desse modo, traria uma carga simbólica ao registro das atividades desenvolvidas, criando, ainda, condiçôes para a construção de memórias dessas escolas.

\footnotetext{
${ }^{5}$ Tradução livre. No original: "en algún momento, Khankhoje, en tono bromista, se reconocería como ‘doblemente índio"”.

${ }^{6}$ Tradução livre. No original: "necesidades de reparto de tierras, de la creación de nuevas variedades de semillas y plantas, del apoyo a ejidatarios, entre muchas otras tareas vinculadas a los planes agrários nacionales". 7 A expressão "Estado-mecenas" foi utilizada por José Vasconcelos para se referir à transição do governo de Obregón para Calles, no final de 1924. Para Vasconcelos, naquele momento, "el Estado-mecenas fracasó, porque la cabeza cambió". [Em tradução livre: "O Estado-mecenas fracassou porque a cabeça mudou] (PRAMPOLINI, 2012, p. 96).
} 
A FOTOGRAFIA PARA ALÉM DO REgISTRO HISTÓRICO: O TRABALHO SOCIAL, PEDAGÓGICO E ARTÍSTICO DE Tina Modotti nas "Escuelas Libres de Agricultura"

Fabiane Taís Muzardo

Segundo a documentaçáo, em dezembro de 1924, o "Congreso de Comunidades Agrarias del Estado de Veracruz" determinou a criação de um programa de ensino agrícola aos camponeses mexicanos, para ajudar a resolver seus problemas socioeconômicos. As primeiras turmas criadas "foram do tipo da Escola Itinerante", com a oferta de cursos com duração de dois anos. Os bons resultados desses cursos comprovaram que os camponeses tinham muito a ganhar com esse ensino.

O resultado da experiência de dois anos nos obriga a mudar este tipo de Escola Itinerante e introduzir um novo sistema de ensino prático e mais apropriado para nossa classe camponesa. Temos que mudar os métodos burgueses e reacionários que existem em quase todas as escolas e, no lugar deste falso ensino, deve-se introduzir uma pedagogia operária-campesina em nossas Escolas Livres. Assim, rejeitamos a Pedagogia burguesa versada sobre a distinção das classes e a exploração do homem para a acumulação de capital ${ }^{9}$.

Para Pandurang, as práticas agrícolas tradicionais "dos latifundiários (capitalistas) baseadas em superstições e más práticas apoiaram a exploração do homem, o que o reduziu a escravo"10. Partindo dessa realidade, ele propunha um novo modelo de agricultura, baseado na exploração racional e científica do campo. Em 1927, a primeira "Escuela Libre de Agricultura" foi criada, com o nome de "Emiliano Zapata, Mártir de los Campesinos". Pandurang desenvolveu um projeto pedagógico que apresentou no "Informe da fundação da Escola Livre de Agricultura 'Emiliano Zapata' organizada pela Liga de Comunidades Agrárias do Estado do México e estabelecido em San Miguel Chiconcuac, Texcoco, México"11, com o título de Princípios Fundamentais do Ensino ${ }^{12}$. Por meio desses princípios, defendia-se que o ensino deveria ser natural e nunca artificial, no sentido de que o aluno deveria sentir necessidade de aprender; além de incentivarem o desenvolvimento do sentimento criador e

\footnotetext{
${ }^{8}$ Acervo da Fototeca Nacional. Ata das "Escuelas Libres de Agricultura" de México, p. 38. Tradução livre. No original: "fueron del tipo de la Escuela Ambulante. Escuelas Libres de Agricultura de México".

${ }_{9}^{9}$ Acervo da Fototeca Nacional. Ata das "Escuelas Libres de Agricultura" de México, p. 33. Traduçáo livre. No original: "Resultado de la experiencia de dos años nos obliga a cambiar este tipo de la Escuela Ambulante y introducir nuevo sistema de la enseńanza practica y mas apropiada para nuestra clase campesina. Tenemos que cambiar métodos burgueses y reacionários que existen en casi todas las escuelas y en lugar de esta falsa enseñanza introducir pegagogia obrera-campesina en nuestras Escuelas Libres. Así rechazamos la Pedagogia burguesa basada sobre distinción de los clases y explotación del hombre para acumulación del capital".

${ }^{10}$ Acervo da Fototeca Nacional. Ata das "Escuelas Libres de Agricultura" de México, p. 33. Tradução livre. No original: "de los latifundistas (capitalistas) basada en la superstición y las malas prácticas, había sustentado la explotación del hombre, que lo reducía a esclavo”.

${ }^{11}$ Acervo da Fototeca Nacional. Ata das "Escuelas Libres de Agricultura" de México, p. 11. Tradução livre. No original: "Informe de la fundación de la Escuela Libre de Agricultura 'Emiliano Zapata' organizada por la Liga de Comunidades Agrarias del Estado de Mexico y estabelecido en San Miguel Chiconcuac, Texcoco, Mexico".

${ }^{12}$ Acervo da Fototeca Nacional. Ata das "Escuelas Libres de Agricultura” de México, p. 10. Tradução livre. No original: "Principios Fundamentales da Enseñanza".
} 
artístico indígena ${ }^{13}$, defendendo, ainda, um ensino que não seguisse "sistemas psicológicos dos estrangeiros que muitas vezes não respondem às necessidades nacionais" ${ }^{\prime \prime}$. As lutas sociais e a arte faziam parte de um mesmo processo. $\mathrm{O}$ trabalho conjunto de uma fotógrafa profissional e de um engenheiro agrônomo indica essa fusão.

Além das propostas diferenciadas de ensino, as escolas agrícolas foram responsáveis pela criação de cooperativas de camponeses, que eram assistidas pelos professores e recebiam sementes e maquinaria para possibilitar sua produção. Em ata de 1928, por exemplo, registrou-se a existência de "galinheiros propriedades dos estudantes com uma quantidade superior a 200 aves" ${ }^{\prime 15}$. Tina fotografou uma dessas cooperativas (Figura 1). Na imagem, os animais ocupam o primeiro plano, enquanto os homens se posicionam na frente de uma parede de tijolos, o estilo de construção que mais aparece nas fotografias. A presença de inúmeras galinhas e da parede de tijolos pode simbolizar uma melhoria na condição de vida dos camponeses que integravam essas escolas.

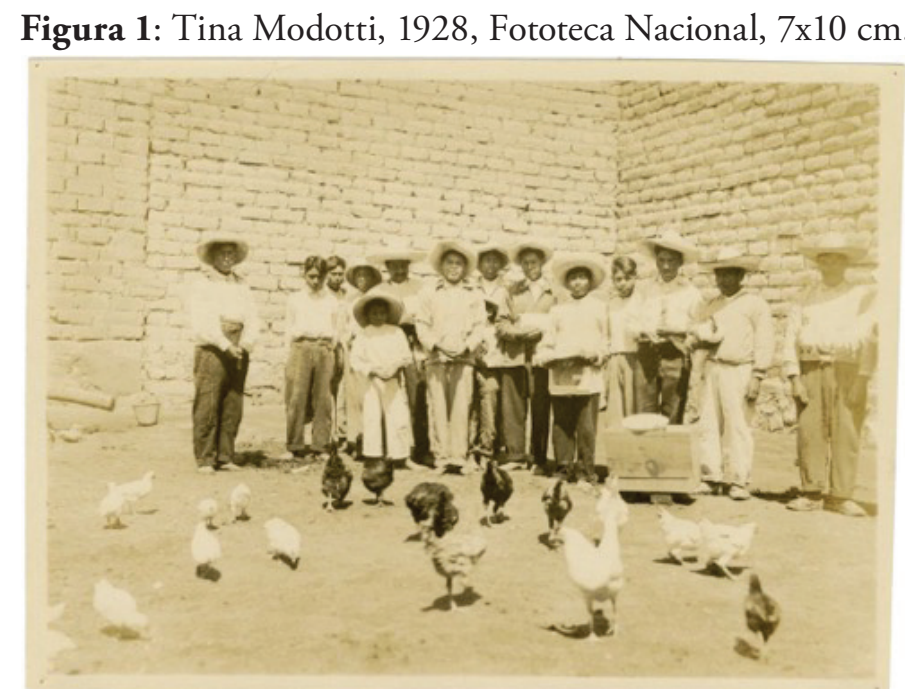

Fonte: Biblioteca Nacional de Fotografia - INAH-SINAFO-MEX

Pandurang via as cooperativas camponesas como a possibilidade de industrializar os campos mexicanos e melhorar a condição socioeconômica dos camponeses. Alguns elementos presentes nas fotografias afirmam e tornam visual esses anseios por uma industrialização

${ }^{13} \mathrm{O}$ tópico 6 dos Principios Fundamentales da Enseñanza diz que a arte e a indústria antiga indígena estão sofrendo atualmente com os imitadores modernos e a escola camponesa está chamada a impulsionar o sentimento artístico indígena, que, em épocas passadas, produziu obras de arquitetura e arte de grande mérito, como demostram as pirâmides de Teotihuacán (tradução livre).

${ }^{14}$ Acervo da Fototeca Nacional. Ata das "Escuelas Libres de Agricultura" de México, p. 10. Tradução livre. No original: "sistemas psicológicos de extranjeros que muchas veces no responden a las necesidades nacionales".

${ }^{15}$ Acervo da Fototeca Nacional. Ata das "Escuelas Libres de Agricultura” de México, p. 15. Tradução livre. No original: "gallineros propiedad de los alumnos con una cantidad no menor de 200 aves en conjunto". 
A FOTOGRAFIA PARA ALÉM DO REgISTRO HISTÓRICO: O TRABALHO SOCIAL, PEDAGÓGICO E ARTÍSTICO DE Tina Modotti nas "Escuelas Libres de Agricultura”

Fabiane Taís Muzardo

e a racionalização que integra esse processo. Em algumas fotografias isso se evidencia pela disciplina e rigidez no posicionamento das pessoas fotografadas, pela postura corporal parecida, pela presença de instrumentos musicais e em tentativas de se parecer "elegante" diante da câmera. Para Pandurang, essas cooperativas deveriam ser constituídas nos "milhares de hectares de terras abandonados que são propriedades do Governo"16, sendo que os camponeses que concluíssem as aulas nas "Escuelas Libres de Agricultura”, em sua visão, estariam aptos para exercer tal trabalho, se lhes fossem oferecidas as condiçóes necessárias, como acesso a sementes e maquinaria.

\section{As especificidades do trabalho de Tina Modotti nas escolas agrícolas}

As fotografias de Tina que compóem essa documentação se diferenciam das outras que produziu por terem um objetivo mais definido: registrar e documentar as açóes e atividades desenvolvidas nessas escolas. Essa afirmativa, contudo, não visa defender a ideia de que tais fotografias estavam isentas de preocupaçóes artísticas e estéticas, e sim que o caráter de testemunho, seguindo a própria concepção de arte defendida por Tina em seu texto "Sobre la fotografia" 17 , fica mais evidente. Pode-se pensar essas fotografias de Tina a partir dos questionamentos realizados por Georges Didi-Huberman, em Pueblos expuestos, pueblos figurantes.

Como fazer a história dos povos? Onde encontrar as palavras dos sem nomes, a escritura dos sem papéis, o lugar dos sem teto, a reinvindicação dos sem direitos, a dignidade dos sem imagens? Onde encontrar o arquivo sobre quem não se quer gravar nada, aqueles cuja memória em si, às vezes, se quer matar? ${ }^{18}$ (DIDI-HUBERMAN, 2014, p. 28).

\footnotetext{
${ }^{16}$ Tradução livre. No original: "milles de hectares de terrenos abandonados que son propriedad del Gobierno". ${ }^{17}$ Para Tina, se as fotografias de sua autoria eram consideradas diferentes das produzidas por outros fotógrafos, é porque ela buscava produzir fotografias honradas, sem manipulação, "mientras que la mayoria de los fotógrafos aún buscan los 'efectos artisticos' o la imitación de otros medios de expresión gráfica” [Em tradução livre: "enquanto que a maioria dos fotógrafos ainda busca 'efeitos-artísticos' ou a imitação de outros meios de expressão gráfica”]. Afirma que, naquele momento, muitas pessoas ainda viviam como se estivessem em séculos passados, sendo "incapaces de aceptar las manifestaciones de nuestra civilización mecânica". Todavia, destaca o quanto os fotógrafos, assim como os pintores, ignoram tais opiniôes adversas, e se valem de seus meios e recursos para trabalhar. Segundo Tina, a fotografia é o meio mais satisfatório para se registrar "la vida objectiva en todas sus manifestaciones; de allí su valor documental, y si a esto se añade sensibilidad y comprensión de asunto, y, sobre todo, una clara orientación del lugar que debe tomar en el campo del desenvolvimento histórico, creo que el resultado es algo digno de ocupar un puesto en la produción social, a la cual todos debemos contribuir" [Em tradução livre: "a vida objetiva em todas as suas manifestaçôes; daí seu valor documental, e se a isso são adicionadas sensibilidade e compreensão do assunto e, acima de tudo, uma orientaçáo clara do seu lugar no campo do desenvolvimento histórico, acredito que o resultado é algo que vale a pena ocupar uma posição na produçáo social, a que todos devemos contribuir”] (MODOTTI, 1929, p. 196).

${ }_{18}$ Tradução livre. No original: "Cómo hacer la historia de los pueblos? Dónde hallar la palabras de los sin nombre, la escritura de los sin papeles, el lugar de los sin techo, la reivindicación de los sin derechos, la
} 
A FOTOGRAFIA PARA ALÉM DO REgISTRO HISTÓRICO: O TRABALHO SOCIAL, PEDAGÓGICO E ARTÍSTICO DE Tina Modotti nas "Escuelas Libres de Agricultura"

Fabiane Taís Muzardo

Tina, ao fotografar, deu visibilidade aos camponeses e camponesas mexicanos, fortaleceu a luta pelo direito à terra e a uma vida digna, além de colaborar para a construçáo de uma memória, a memória dos sem nome. Segundo Didi-Huberman (2014, p. 13), "a imagem mantém, é verdade, uma relação antropológica de longa data com a questão do direito civil,

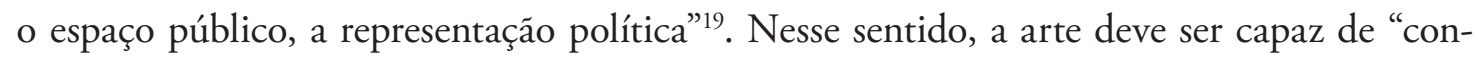
quistar uma 'parcela da humanidade' [...] com a condição de fazer a 'história narrável'"20 (DIDI-HUBERMAN, 2014, p. 26). Os elementos que eram comuns aos camponeses e camponesas das escolas agrícolas, assim como os aspectos que os diferenciavam de outros grupos, se evidenciam nas fotografias de Tina, reforçando o sentimento de pertencimento às escolas agrícolas.

Essas fotografias de Tina são pouco conhecidas, quando comparadas às demais que produziu. Isso se deve ao fato de essa documentação ter se tornado pública há poucos anos. Isso ocorrer quase um século após sua produção possibilitou que esses camponeses e camponesas fossem olhados novamente, daí nosso argumento de que as fotografias, junto à narrativa das atas, criaram memórias, ainda que elas tenham permanecido em silêncio durante tantos anos. Esse retorno, que possibilitou nova visibilidade, pode ser entendido a partir da ideia de sobrevivência, seguindo a concepção warburguiana. Tal concepção se volta não para o que se altera, e sim para o que permanece, "sob a forma de uma energia viva da memória social, inculcada na fórmula de páthos" (GUERREIRO, 2012, p. 04). Entende-se páthos como uma fórmula de intensidade do passado que permanece, voltado não para uma memória consciente e sim para aquilo que "se esquece". Didi-Huberman (2016, p. 20), em "Que emoção! Que emoção?", afirma que o termo "patético tem uma longa e belíssima história", por se tratar de uma palavra grega que foi táo importante para autores como Ésquilo e Sófocles quanto "logos" foi para Aristóteles e Platão. Segundo Didi-Huberman, Aristóteles deduziu a palavra páthos como a "voz passiva" de um verbo, gramaticalmente falando. "A partir disso, entendemos melhor que o fenômeno da emoção esteja ligado ao páthos, quer dizer, à paixão, à passividade, ou à impossibilidade de agir” (DIDI-HUBERMAN, 2016, p. 20). Didi-Huberman, todavia, se vale de outros autores para redimensionar a ideia de páthos, defendendo a emoção como um movimento, e, portanto, uma ação. Da passividade à ação. Da ação à transformação.

Provavelmente, mesmo sendo um documento oficial, o fato de ser uma instituição voltada para o povo tenha colaborado para esse silenciamento. Rosane Kaminski, ao trabalhar com o conceito de memória, afirma existir "grande diferença entre uma memória coletiva

dignidade de los sin imágenes? Dónde hallar el archivo de aquellos de quines no se quiere consignar nada, aquellos cuya memoria misma, a veces, se quiere matar?"

${ }^{19}$ Tradução livre. No original: "la imagen mantiene, es verdade, una relación antropológica de muy larga data con la cuestión del derecho civil, el espacio público, la representación política”.

${ }^{20}$ Tradução livre. No original: "conquistar una 'parcela da humanidade' [...] con la condición de hacer la 'historia narrable”". 
A FOTOGRAFIA PARA ALÉM DO REGISTRO HISTÓRICO: O TRABALHO SOCIAL, PEDAGÓGICO E ARTÍSTICO DE Tina Modotti nas "Escuelas Libres de Agricultura"

Fabiane Taís Muzardo

que se manifesta ritualmente, sendo da ordem da vivência, e uma memória nacional, de ordem ideológica, produto de uma história social que calcifica a tradição" (KAMINSKI, 2001, p. 6). Nesse caso, contudo, a memória é, ao mesmo tempo, resultado da vivência e de ordens ideológicas, basta pensar no cotidiano das atividades desenvolvidas nas escolas agrícolas e nas lutas políticas e sociais, principalmente voltadas para a questão agrária, que marcaram a década de 1920 no México.

Segundo Duque, a análise dessa documentação nos permite conhecer o trabalho da "tríade: Khankhoje, Rivera e Modotti, reunidas sob o tema da agricultura, do milho e da luta social"21 (DUQUE, 2015, p. 10). Existem divergências sobre o contexto em que Tina e Pandurang se conheceram. Alguns autores, como Artemio Cruz León, Marcelino Ramírez Castro e Duque (2015), afirmam que isso ocorreu em 1926, quando Tina trabalhava com Rivera. Hooks (1997), por sua vez, afirma que esse encontro ocorreu antes, nas festas e reuniôes que Tina promovia em sua casa, logo depois de sua mudança para o México. Nas cartas escritas por Tina, há uma menção a Pandurang datada de $1^{\circ}$ de abril de 1927. Nessa carta, endereçada a Weston, Tina escreveu sobre uma reunião de amigos organizada por Frances Toor e ressaltou a presença de Pandurang: "Também esteve Konkhoje - Que boa pessoa é! E à noite não sei como cheguei a estar mais perto dele como nunca! Falamos de ti e me implorou para dizer que se lembra muito de você" (SABORIT, 2001, p. 160)22. O fato de Pandurang conhecer Weston e recordar momentos em que conviveram, reforça o argumento de que Tina e Pandurang se conheceram antes de 1926, visto que Weston saiu definitivamente do México, retornando aos Estados Unidos, no ano de 1926. Independentemente do momento em que tal encontro ocorreu, fica claro que o contato entre eles se manteve, afinal, eles estavam juntos em diferentes contextos. A potência desse encontro se torna evidente quando, tanto tempo depois, o protagonismo de camponeses e camponesas mexicanos no período pós-revolucionário ganha nova projeção e torna-se, novamente, tema de discussóes.

\section{Tina nos documentos de fundação das "Escuelas Libres de Agricultura"}

A primeira página da ata de criação das escolas agrícolas, datada de 1927, ainda que não mencione o nome de Tina, contém duas referências ao seu trabalho: o símbolo das escolas agrícolas, feito a partir de uma fotografia de Tina; e uma fotografia de sua autoria (Figura 2).

\footnotetext{
${ }^{21}$ Tradução livre. No original: "tríada: Khankhoje, Rivera e Modotti, reunida bajo el tema de la agricultura, el maíz y la lucha social”.

${ }^{22}$ Existem divergências quanto à grafia do nome de Pandurang.
} 
Figura 2: Tina Modotti, 1928, Fototeca Nacional

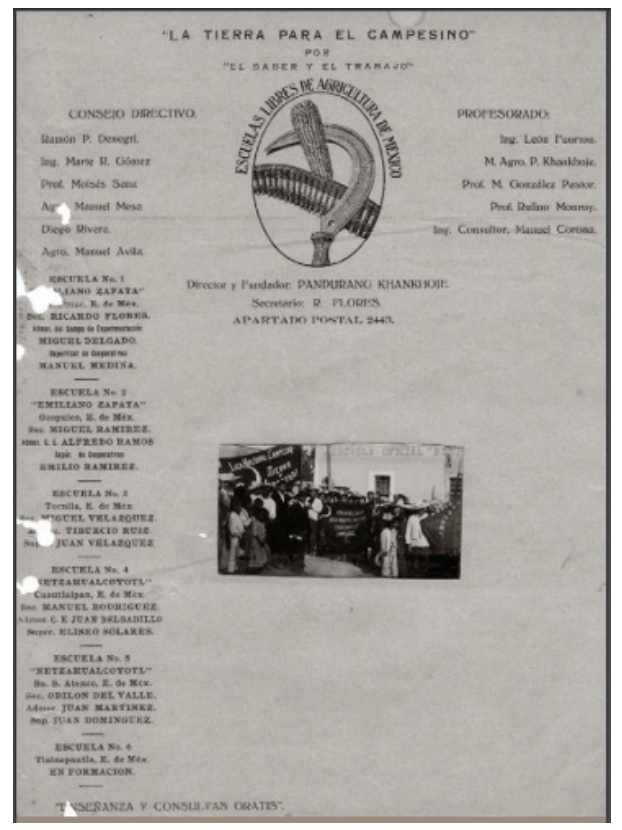

Fonte: Biblioteca Nacional de Fotografia - INAH-SINAFO-MEX

O símbolo e selo oficial das escolas agrícolas, reproduzido inúmeras vezes no documento, foi feito com base na fotografia "Hoz, Canana e Mazorca", também datada de 1927. Patricia Massé (2014, p. 36-37) defende que "não seria estranho que Tina tivesse procurado essa composição com a consciência de criar o emblema para as Escolas Livres de Agricultura"23. Apesar de ser uma hipótese plausível, há de se lembrar que Tina produziu, em meados de 1927, inúmeras fotografias com elementos que, reunidos, criavam uma carga simbólica. Portanto, tão plausível quanto Tina ter criado essa fotografia para que ela servisse, posteriormente, como emblema dessas escolas, numa espécie de encomenda, é a hipótese de que sua fotografia tenha sido escolhida para se tornar esse emblema, justamente por sua simbologia. Nesse caso, nota-se novamente a atuação de Tina enquanto produtora de imagens com finalidades políticas, haja vista a produção de um emblema para as escolas agrícolas, o qual tem imbricado um sentido de perenidade, além de unir as ações dessas escolas com as lutas comunistas. De Massé nos parece mais interessante a percepção de que, nessa imagem, tanto na fotografia quanto no selo, há uma síntese de três revoluçóes: a mexicana, a bolchevique e a revolução verde, "impulsionada com os projetos pedagógicos das Escolas Livres de Agricultura no México, cujo fundador foi Pandurang"24 (MASSÉ, 2014, p. 40).

\footnotetext{
${ }^{23}$ Tradução livre. No original: "no sería nada rara que Tina hubiera buscado esa composición con la consciencia de crear el emblema para las Escuelas Libres de Agricultura".

${ }^{24}$ Tradução livre. No original: "impulsada con los proyectos pedagógicos en las Escuelas Libres de Agricultura en México, cuyo fundador fue Pandurang”.
} 
A FOTOGRAFIA PARA ALÉM DO REgISTRO HISTÓRICO: O TRABALHO SOCIAL, PEDAGÓGICO E ARTÍSTICO DE Tina Modotti nas "Escuelas Libres de Agricultura"

Fabiane Taís Muzardo

A fotografia, por sua vez, se destaca pelo simples fato de ter sido colocada na primeira página da ata, numa espécie de capa. Nela, nota-se a presença de homens, mulheres e crianças, sendo que alguns olham diretamente para a câmera, com destaque para a menina, localizada no canto esquerdo, que, estando de lado para a câmera, virou a cabeça para olhá-la, provavelmente movida pela curiosidade que aquele aparelho lhe causara. Trata-se, ainda, da primeira fotografia em que Pandurang aparece. Ele é o homem, no centro da imagem, que usa terno, chapéu e segura um papel em suas mãos. Interessante que, aqui, a fotografia aparece sem nenhuma legenda. Em ata de 1928, contudo, essa mesma fotografia reaparece, com outro recorte, mais aberto, que possibilita visualizar mais camponeses.

Essa fotografia, mesmo registrando um grupo de pessoas, nos possibilita ver o rosto, identificar camponeses. É nesse sentido que entendemos que o trabalho de Tina, ainda que tenha o objetivo de registrar as atividades realizadas nas escolas, deu visibilidade e colaborou para a criação de memória. Memórias de anônimos. Estaríamos, portanto, no limiar entre o individual e o coletivo: nas fotografias de Tina, é possível identificar a individualidade dos camponeses e a coletividade da comunidade desses mesmos camponeses, a qual "é muito maior, mais profunda e mais transversal do que cada pequeno 'eu' individual” (DIDI-HUBERMAN, 2016, p. 30).

A primeira menção direta ao nome de Tina ocorreu em ata datada de 15 de janeiro de 1928, que registrou a "reabertura das classes técnico-agrícolas" ${ }^{2}$. Além dessa menção, nessa mesma ata há um agradecimento ao trabalho desenvolvido por Tina. No escrito, registrou-se que as fotografias de Tina foram dadas como prêmios para os camponeses que se destacaram em uma competição realizada na escola agrícola.

Tina fotografou um momento dessas competições. Na imagem (Figura 3), a câmera parece não ser notada por todos os homens que a protagonizam. Apenas dois homens, ao lado esquerdo e ao fundo da imagem, olharam para a câmera. Mesmo assim, é um olhar que não encara a câmera, apenas a percebe. A fotografia, desse modo, parece criar um ar de naturalidade, como se aqueles que confraternizavam durante a inauguração da escola número 2, nem percebessem que "virariam imagens". Essas percepçóes ajudam a entender a forma como Tina era aceita nesse espaço: o modo como desenvolveu seu trabalho e conviveu com as pessoas fez com que ela integrasse o grupo, reforçando a concepção de pertencimento às escolas agrícolas e suas lutas sociais.

\footnotetext{
${ }^{25}$ Acervo da Fototeca Nacional. Ata das "Escuelas Libres de Agricultura” de México, p. 9. Traduçáo livre. No original: "reapertura de las clases técnico-agrícolas".
} 
Figura 3: Tina Modotti, 1928, Fototeca Nacional, 10,2 x 12,7 cm.

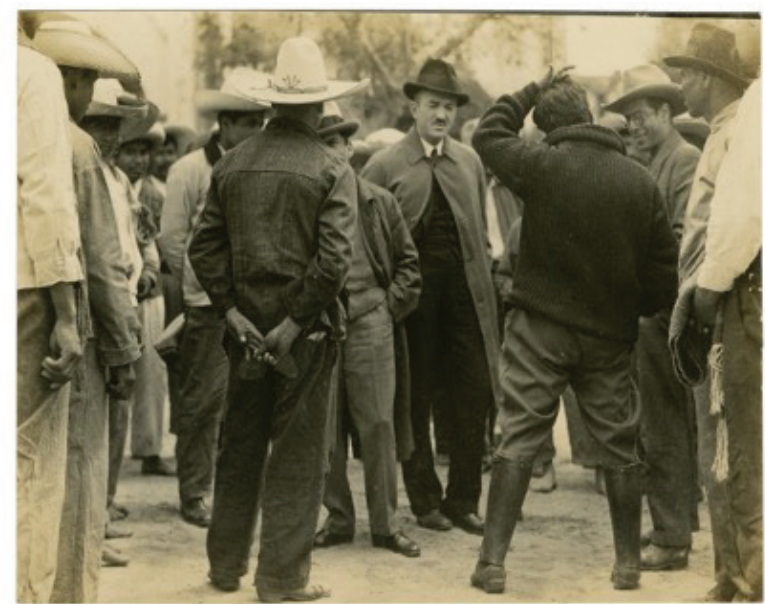

Fonte: Biblioteca Nacional de Fotografia - INAH-SINAFO-MEX

Autores como Rosane Kaminski (2012) e Ismael Xavier (2009) analisaram esse olhar que denuncia a presença daquele que produz a imagem. Para Kaminski, a presença da câmera gera alteraçóes na realidade que se quer documentar, ainda que muito sutis. Xavier, por sua vez, analisando esse "olhar" por parte de operários de uma fábrica, afirma que essa denúncia pode ser entendida como "imprevisto", pela impossibilidade de todo o tempo se controlar a reação daqueles que se filma, ou como "retórica calculada", uma vontade de se denunciar tal presença. De qualquer modo, pode-se dizer que o "olhar para a câmera" indica a "artificialidade da imagem”, por meio da presença tanto do dispositivo quanto do fotógrafo.

Tina produziu várias fotografias de alunos e professores em frente às fachadas das escolas, nas quais podem-se visualizar as janelas, portas e os letreiros com os nomes das instituiçôes (Figura 4). Nessas imagens, boa parte das pessoas fotografadas usa sombreros, incluindo as crianças. Os sombreros acabam ocultando o rosto de alguns camponeses, principalmente dos posicionados ao fundo do grupo. Todavia, é possível visualizar o rosto dos camponeses das primeiras filas, tanto dos que usam quanto dos que não usam sombreros. $\mathrm{O}$ resultado desse ocultar/visualizar o rosto é interessante: ao mesmo tempo que se tem alusão à coletividade, pelo ocultar dos rostos, tem-se a individualidade dos camponeses sendo registrada. Essa individualidade/coletividade pode ser pensada a partir da análise desenvolvida por Hannah Arendt sobre o aparecer político dos povos, na qual ela afirma que

os povos não são abstrações, são feitos de corpos que falam e atuam. Apresentam, expóem seus rostos. Multiplicidades, certamente: tudo isto constitui uma multitude sem número de singularidades - movimentos singulares, desejos singulares, palavras singulares, açóes singulares - sua síntese não poderia fazer nenhum conceito. Por isto não há que dizer "o homem" ou "o povo", senão, na verdade, "os homens", "os povos". A política - disse Arendt -, 
A FOTOGRAFIA PARA ALÉM DO REGISTRO HISTÓRICO: O TRABALHO SOCIAL, PEDAGÓGICO E ARTÍSTICO DE Tina Modotti nas "Escuelas Libres de Agricultura"

Fabiane Taís Muzardo

se baseia em um fato: a pluralidade humana ${ }^{26}$ (ARENDT, 1959 apud DIDI-HUBERMAN, 2014, p. 22).

A possibilidade de ver o rosto dos camponeses e identificar sua presença em mais de uma fotografia reforça esse aparecer político dos povos.

Figura 4: Tina Modotti, 1928, Fototeca Nacional, 6,5 x $10 \mathrm{~cm}$ e 10,2 x 12,7 cm.
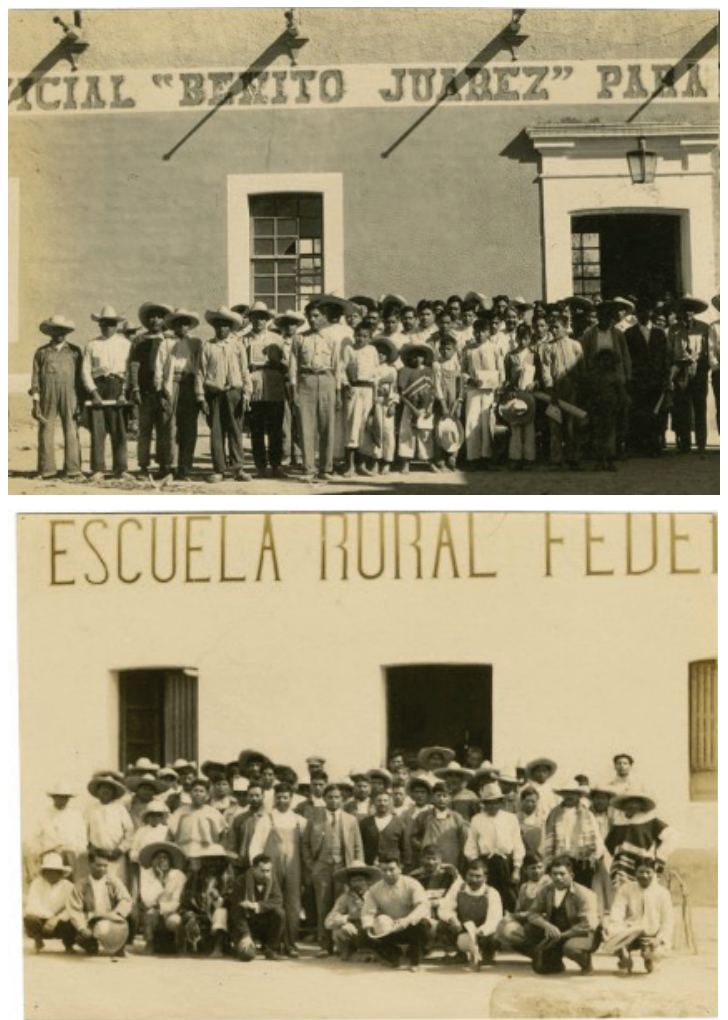

Fonte: Biblioteca Nacional de Fotografia - INAH-SINAFO-MEX

Trata-se, obviamente, de fotografias posadas, que seguem mesmo padrão de composição. Arlindo Machado (2015, p. 60) afirma que essa pose diante da câmera é a luta para "introjetar no momento aleatório da fotografia o momento ideal da pintura [...]. A pose é uma espécie de vingança do referente: se for inevitável que a câmera roube alguma coisa de nós, que ela roube, então, uma ficção”. A câmera, portanto, nunca é passiva diante de seu objeto, por impor um determinado arranjo, "uma configuração das coisas pela força de sua simples

\footnotetext{
${ }^{26}$ Tradução livre. No original: "los pueblos no son abstraciones, están hechos de cuerpos que hablan y actúan. Presentán, exponen sus rostros. Multiplicidades, desde luego: todo esto constituye una multitud sin número de singularidades - movimientos singulares, deseos singulares, palabras singulares, acciones singulares suya sínteses no podría hacer ningún concepto. Por esto no hay que decir 'el hombre' o 'el pueblo', sino, en verdade, 'los hombres', 'los pueblos'. La politica - dice Arendt -, se basa en un hecho: la pluralidad humana”.
} 
A FOTOGRAFIA PARA ALÉM DO REGISTRO HISTÓRICO: O TRABALHO SOCIAL, PEDAGÓGICO E ARTÍSTICO DE Tina Modotti nas "Escuelas Libres de Agricultura"

Fabiane Taís Muzardo

presença”" (MACHADO, 2015, p. 65). Essa escolha por uma fotografia nitidamente posada também pode ser associada a uma função educativa da imagem, de colocar um ideal de composição e de beleza na produção dessas fotografias, ainda que tal ideal seja originário da pintura. Essa produção educa o gosto e a percepção estética.

Nessas fotografias, é possível perceber o quanto as pessoas se "organizaram" no espaço para caber no enquadramento, ajustando-se a um determinado cenário. Seguindo os comandos de Tina, se posicionaram e se "tornaram imagens". Segundo Didi-Huberman (2014, p. 39), "uma fotografia, é certo, não devolve a palavra ao sujeito fotografado [...]. Mas erguer os rostos, mantê-los, devolvê-los ao seu poder de encarar, não é expô-los à dimensão de uma possiblidade de palavra?" ${ }^{27}$. O registro da presença em massa dos camponeses nessas escolas em um momento em que se lutava pela concretização da reforma agrária, no pós-revolução, somado ao fato de essas imagens se tornarem públicas tanto tempo depois e serem objeto de análise, tem uma carga simbólica bastante significativa. Na década de 1920, sob a mirada de Tina, esses camponeses foram vistos como protagonistas de um projeto agrícola; hoje, compóem uma memória visual de luta social.

$\mathrm{Na}$ documentação, existem seis fotografias de aulas e reuniôes. Nessas imagens, Tina posicionou de diferentes modos sua câmera: em quatro fotografias, o ângulo de tomada seguiu a visão dos alunos, enquanto nas outras duas imagens, a visão dos professores. Também variou a posição dos planos de enquadramento: ora frontal, ora diagonal. Pela posiçáo da câmera, percebe-se o quanto a presença de Tina era aceita em todos os espaços das escolas. Nas imagens que seguem a visão dos alunos, nenhum aluno olhou para a câmera, denunciando sua presença. Em uma delas, contudo, um aluno se voltou para trás e olhou diretamente para a câmera. Em uma das fotografias, Tina optou por um enquadramento mais aberto, fotografando, além dos alunos, a estrutura da escola. Essa escolha pode ter relaçáo com o fato de se tratar da terceira escola agrícola criada: a fotografia "comprovaria" o crescimento desse projeto. O destaque dado à arquitetura da escola acaba por enaltecer o trabalho coletivo de todos os agentes que a compunham. Mesmo nas imagens produzidas a partir do ângulo de visão dos professores, percebe-se que Tina posicionou a câmera num ângulo normal, seguindo o nível dos olhos dos alunos, o que evidencia o caráter igualitário e coletivo das escolas.

\footnotetext{
${ }^{27}$ Traduçáo livre. No original: "una fotografia, es cierto, no devuelve la palabra al sujeto fotografiado [...]. Pero erguir los rostros, sosternelos, devolverlos a su poder de encarar, no es ya expornerlos en la dimensión de una posibilidad de palabra?".
} 
Figura 5: Tina Modotti, 1928, Fototeca Nacional, 10,2 x 12,7 cm
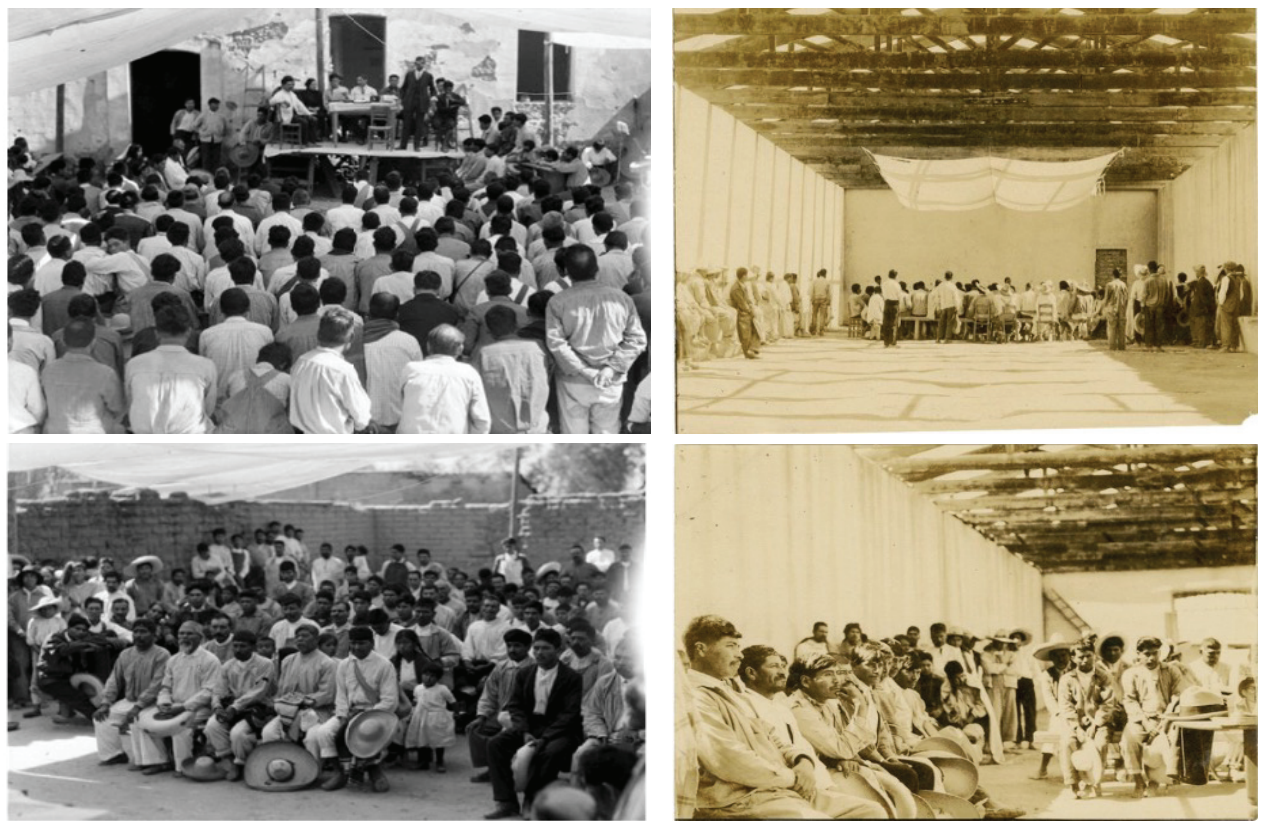

Fonte: Biblioteca Nacional de Fotografia - INAH-SINAFO-MEX

Tina ainda produziu dezoito fotografias das atividades realizadas nas escolas agrícolas. Dessas, destacam-se três imagens ligadas a apresentaçôes artísticas. Na primeira delas, Tina fotografou a banda de música de Chiconcuac. Na imagem, treze homens posaram para a fotografia, oito segurando instrumentos musicais. Não há referências ao local em que a fotografia foi produzida. Mesmo assim, percebe-se que houve a escolha de um local diferenciado, pela presença do muro repleto de detalhes e da árvore, que ocupa a porção superior esquerda da imagem. Esse tipo de escolha se contrapóe à ideia defendida por Massé (2014, p. 40) de que o trabalho de registrar as atividades cotidianas das escolas fez com que as exigências formais das fotografias de Tina tivessem que "adequar-se às circunstâncias ordinárias”28. Ainda que existisse esse objetivo de registar e documentar uma atividade, é possível perceber uma série de escolhas estéticas na fotografia de Tina. O muro, por exemplo, cria uma espécie de linha imaginária que separa os homens do ambiente em que estão, o qual ocupa mais da metade do enquadramento da imagem. A presença do muro ainda evoca ordem, disciplina e uma organização do olhar. Parece que Massé, ao analisar as fotografias de Tina seguindo a ideia de que existem fases em sua produção ${ }^{29}$, desassociou forma e conteúdo, ressaltando o

\footnotetext{
${ }^{28}$ Tradução livre. No original: "adecuarse a las circunstancias ordinárias".

${ }^{29}$ Essa característica se faz presente na maioria dos estudos sobre Tina. Nessa leitura, as fotografias de Tina costumam ser divididas em dois momentos: uma primeira fase considerada "artística"; e a segunda fase, marcada por "fotografias engajadas". A demarcação temporal dessas fases seria definida pela filiação de Tina ao PCM, ocorrida em 1927. Contudo, ainda que seja possível realizar tal divisão, há de se ressaltar que a produção fotográfica de Tina se caracterizou pela fluidez entre temáticas artísticas e politizadas: ao mesmo
} 
aspecto "formal", no que denominam de "primeira fase" da produção de Tina; e o conteúdo, na "segunda fase", defendendo, desse modo, que tais imagens, por terem sido produzidas em 1928 - portanto, após a filiação de Tina ao PCM - somente poderiam ser entendidas a partir de seu aspecto temático. Essa análise linear, contudo, reduz a complexidade da fotografia de Tina. Adaptando a teoria de Serge Gruzinski (2007, p. 68), entendemos o trabalho de Tina como algo que não pode ser lido e entendido a partir de uma única evolução, e sim a partir de "bifurcaçóes, travessias e atoleiros"

Nas imagens seguintes (Figura 6), Tina novamente fotografou pessoas na frente de um muro, que, juntamente com as pedras onde as pessoas estão sentadas, parecem formar um cenário no qual uma mulher se apresenta. Ao fundo, novamente tem-se árvores. Pode-se dizer que, mesmo em "situaçôes ordinárias", fazendo referência à expressão de Massé, Tina prezou, como sempre, pela estética de seu trabalho. Nessa fotografia, contudo, o muro é "irregular", não gerando a mesma "ordem" que se percebe na fotografia anterior. Essa "irregularidade" sugere uma descontração. Tina fotografou duas vezes esse momento: no primeira caso, a mulher ocupa o centro da imagem e tem poucas pessoas ao seu redor; na segunda fotografia, ela pode passar despercebida a olhos desatentos. Contudo, ela permanece sentada no mesmo lugar. Ao seu redor, há um número maior de pessoas, incluindo homens, mulheres e crianças. A individualidade/coletividade se faz presente novamente.

Figura 6: Tina Modotti, 1928, Fototeca Nacional, 10,2 x 12,7 cm

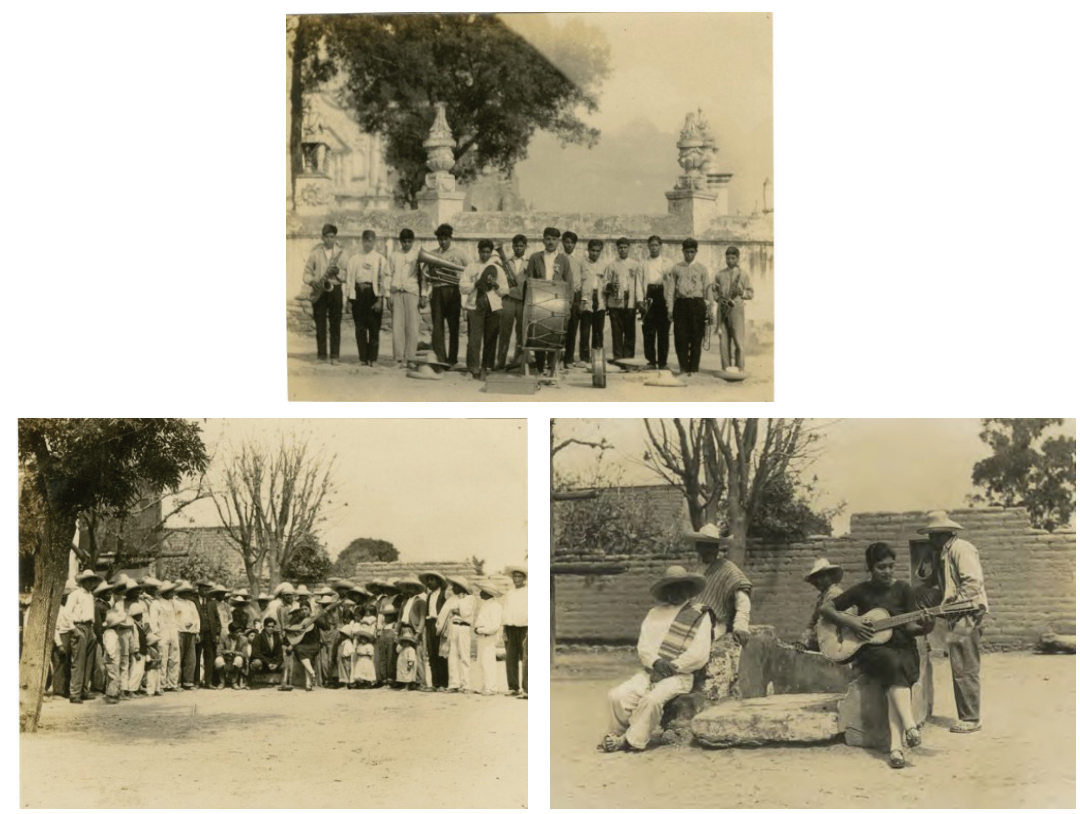

Fonte: Biblioteca Nacional de Fotografia - INAH-SINAFO-MEX

tempo em que produziu fotografias de símbolos comunistas, fotografou murais, escolas agrícolas, a arquitetura mexicana, mulheres, crianças etc.

${ }^{30}$ Tradução livre. No original: "bifurcaciones, travesías y atolladeros". 
Nas fotografias que compóem essa documentação, em muitas vezes é possível perceber a presença de crianças. Em uma ocasiáo, contudo, as crianças protagonizaram a fotografia (Figura 7). Trata-se de uma imagem das crianças que estudavam na primeira escola agrícola criada. Ao lado de um numeroso grupo de crianças, há uma única mulher adulta. A simplicidade do grupo se evidencia nos detalhes: das seis crianças que se encontram no primeiro plano da imagem, apenas uma usa sapatos, a que se encontra na extremidade esquerda da imagem; todas as outras estão descalças. Ainda que o grupo tenha posado para ser fotografado, olhando diretamente para a câmera, duas crianças, a que usa lenço e a menor delas, se voltaram para o extracampo da imagem. Algo localizado nesse lugar que nunca veremos atraiu a atençấo das duas, fazendo, inclusive, com que a menor delas sorrisse. Apesar de todos os elementos presentes na imagem, nos detemos naquilo que nunca poderemos ver, que somente pode ser imaginado. Para Didi-Huberman (2014), o enquadramento da fotografia "aprisiona" aqueles que são fotografados. Nesse caso, contudo, ainda que as crianças tenham sido posicionadas de uma determinada maneira, para que a fotografia pudesse ser produzida com boas condições, duas delas "fugiram desse aprisionamento". O olhar para fora do enquadramento e o sorriso da criança podem, desse modo, ser entendidos como uma exposiçáo mais honesta de suas emoçóes.

Figura 7: Tina Modotti, 1928, Fototeca Nacional, 10,2 x 12,7 cm.

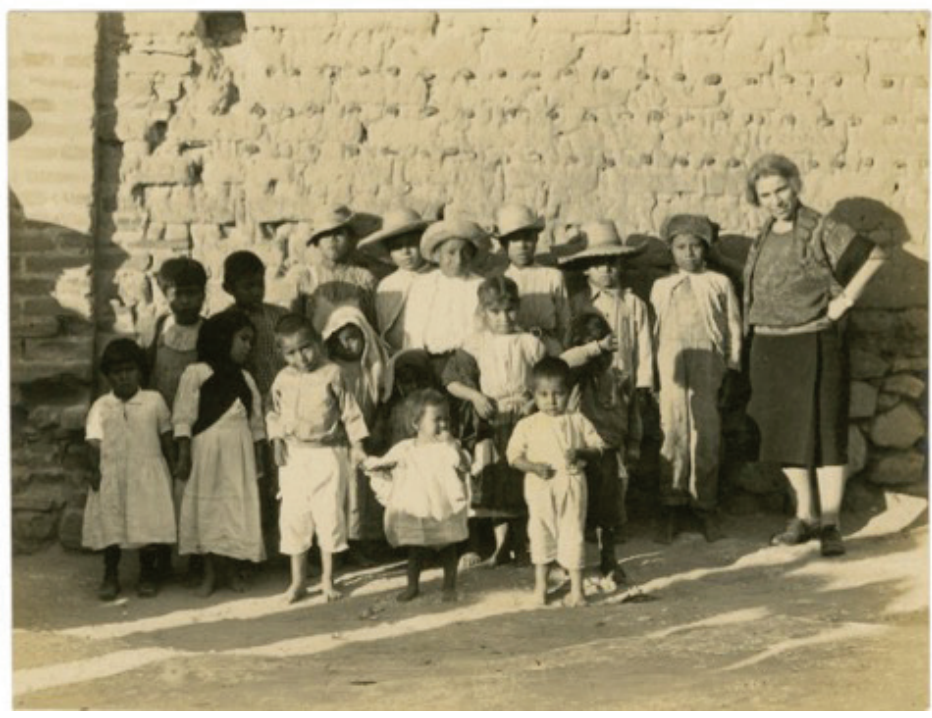

Fonte: Biblioteca Nacional de Fotografia - INAH-SINAFO-MEX

Tina ainda produziu duas fotografias de visitantes enviados às Escolas Agrícolas (Figura 8). Uma delas também foi publicada no periódico El Machete, na edição de 25 de agosto de 1928; a segunda fotografia, por sua vez, ainda que tenha um caráter oficial, possui um "clima de descontração", indicada pelas mãos no bolso e pernas relaxadas dos homens fo- 
A FOTOGRAFIA PARA ALÉM DO REgISTRO HISTÓRICO: O TRABALHO SOCIAL, PEDAGÓGICO E ARTÍSTICO DE Tina Modotti nas "Escuelas Libres de Agricultura"

Fabiane Taís Muzardo

tografados. A menção escrita e visual da presença de autoridades do governo mexicano nas escolas reforça a existência do que José Vasconcelos ${ }^{31}$ denominou de "Estado-mecenas".

Figura 8: Tina Modotti, 1928
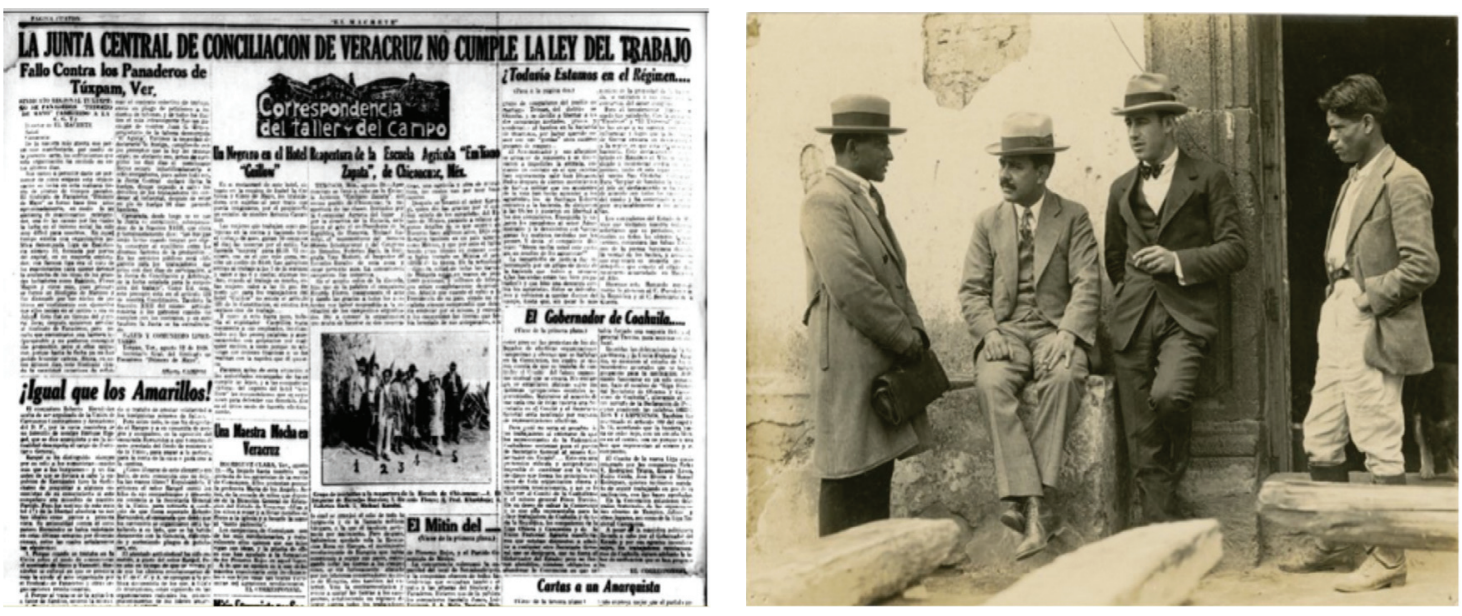

Fonte: El Machete, 25 de agosto de 1928, p. 4.

Biblioteca Nacional de Fotografia - INAH-SINAFO-MEX

Esse "clima de descontração" pode indicar que os homens fotografados não perceberam a presença da câmera e, portanto, não sabiam que "virariam imagens". Susan Sontag destaca esse desejo que possuímos de que o fotógrafo

seja um espião na casa do amor e da morte e que as pessoas fotografadas não estejam conscientes da câmera, estejam "desprevenidas". Nenhuma ideia sofisticada do que a fotografia é ou pode ser jamais enfraquecerá a satisfação proporcionada por uma foto de um acontecimento inesperado, apanhado em pleno curso, por um fotógrafo alerta (SONTAG, 2003, p. 49).

Apesar das diferenças de vestimentas, a posição dos homens, sem uma ordem rígida, indica a coletividade e igualdade entre as pessoas que compunham as escolas agrícolas, sejam elas professores, diretores ou alunos. Interessante pensar que Tina, em muitos momentos, estava inserida em um ambiente predominantemente masculino, ainda que tanto homens quanto mulheres pudessem se matricular nas escolas. A individualidade/coletividade dessas escolas agrícolas se evidencia, também, ao se perceber que um aluno pode ser identificado

\footnotetext{
${ }^{31}$ José Vasconcelos nasceu em Oaxaca, no México, no ano de 1882. Em 1909 colaborou ativamente para a fundação do "Ateneo de la Juventude", grupo que questionava a filosofia oficial mexicana. Foi reitor da Universidade Nacional do México, atual Universidade Nacional Autônoma do México - UNAM, entre os anos de 1920 e 1921. Nesse mesmo ano se tornou o primeiro secretário da Educação no México, cargo que ocupou até 1924. Dentre outras obras, escreveu Ulisses Criollo, um livro de memórias, e La Raza Cósmica.
} 
A FOTOGRAFIA PARA ALÉM DO REgISTRO HISTÓRICO: O TRABALHO SOCIAL, PEDAGÓgICO E ARTÍSTICO DE Tina Modotti nas "Escuelas Libres de Agricultura"

Fabiane Taís Muzardo

em duas fotografias de Tina (Figura 9), o que reforça nosso argumento de que Tina colaborou para a construção de uma identidade individual e coletiva nessas escolas. Segundo Didi-Huberman,

Há que assumir o gesto de estar perto, como uma maneira de marcar em nosso próprio corpo e reconhecer o outro como tal. Para que o rosto apareça como outro frente a nós, não basta capturá-lo: é preciso, ademais, que surja, que coloque em questấo a superfície de si e o espaço da representação ${ }^{32}$ (DIDI-HUBERMAN, 2014, p. 175).

Ainda que não possamos conhecer a biografia desse camponês fotografado, ainda que ele permaneça um anônimo, ele integrou a história e a memória das escolas agrícolas. Essa percepção somente foi possível pela existência das fotografias de Tina, uma vez que, na documentação escrita, os dados são gerais, de cada uma das escolas criadas, sem especificidades aos alunos que nelas estudavam.

Figura 9: Tina Modotti, 1928, Fototeca Nacional, 10,2 x 12,7 cm.
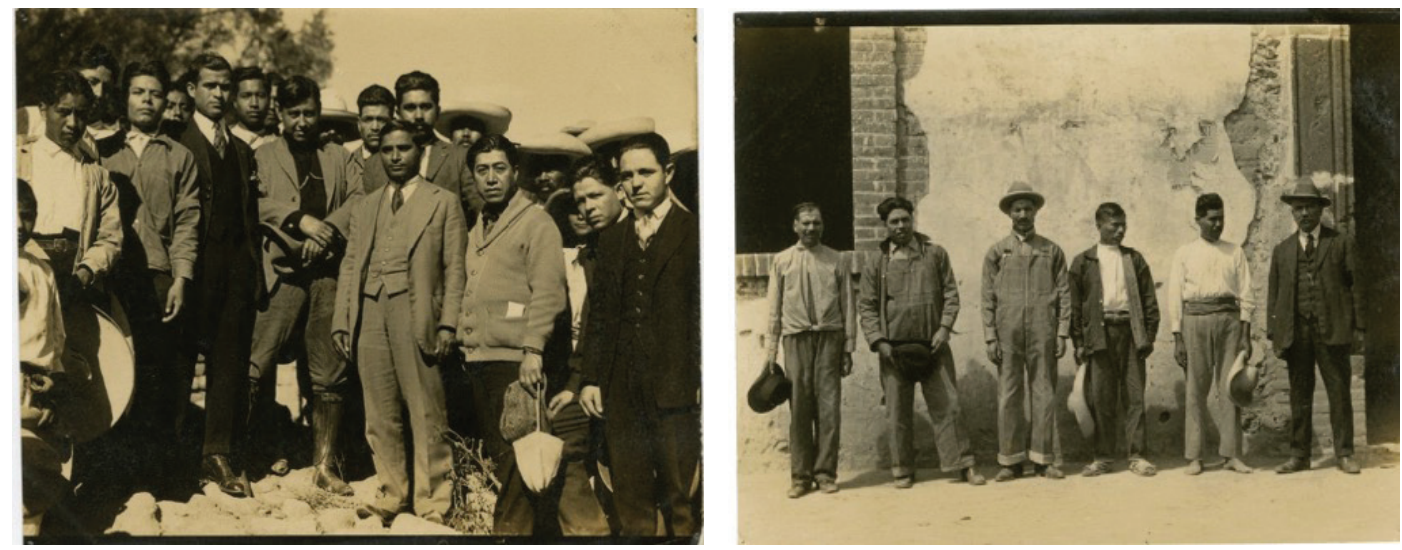

Fonte: Biblioteca Nacional de Fotografia - INAH-SINAFO-MEX

Rivera aparece em uma imagem produzida por Tina (Figura 10) durante esse trabalho nas escolas agrícolas. Trata-se do momento em que os alunos lhe entregaram uma bandeira, em homenagem aos serviços prestados nas escolas. Nas atas, somente menciona-se a realização dessa homenagem, sem mais informações sobre o evento. Nessa fotografia, os olhares dos fotografados se voltaram para a câmera ou para Rivera. Quanto ao ambiente, na lateral direita há um muro, e, ao fundo, árvores. Pode-se perceber, desse modo, uma recorrência de

\footnotetext{
${ }^{32}$ Tradução livre. No original: "Hay que asumir el gesto de acercarse, como una manera de marcar en nuestro propio cuerpo de mirador el acto de reconocer al outro como tal. Para que el rostro aparezca como outro ante nosotros, no basta con captarlo: es preciso además que emerja, que ponga en cuestión la superfície misma y el espacio de la representación".
} 
A FOTOGRAFIA PARA ALÉM DO REGISTRO HISTÓRICO: O TRABALHO SOCIAL, PEDAGÓGICO E ARTÍSTICO DE Tina Modotti nas "Escuelas Libres de Agricultura"

Fabiane Taís Muzardo

elementos fotografados nas imagens produzidas em ambientes externos às escolas. A faixa carregada pelos camponeses tem os dizeres: "Emiliano Zapata não está morto, ele vive no coração dos camponeses" ${ }^{\prime 3}$. Percebe-se, desse modo, uma política cultural praticada pelos integrantes das escolas agrícolas que fortalecia o lado derrotado da Revolução. Além de as escolas carregarem o nome de Zapata, esse líder camponês era rememorado nas atividades desenvolvidas. Tem-se, assim, um lado político evidente nessa imagem, o qual, apesar de integrar um projeto oficial de expansão das escolas agrícolas, homenageia um dos maiores símbolos da Revolução Mexicana.

Figura 10: Tina Modotti, 1928, Fototeca Nacional, 10,2 x 12,7 cm

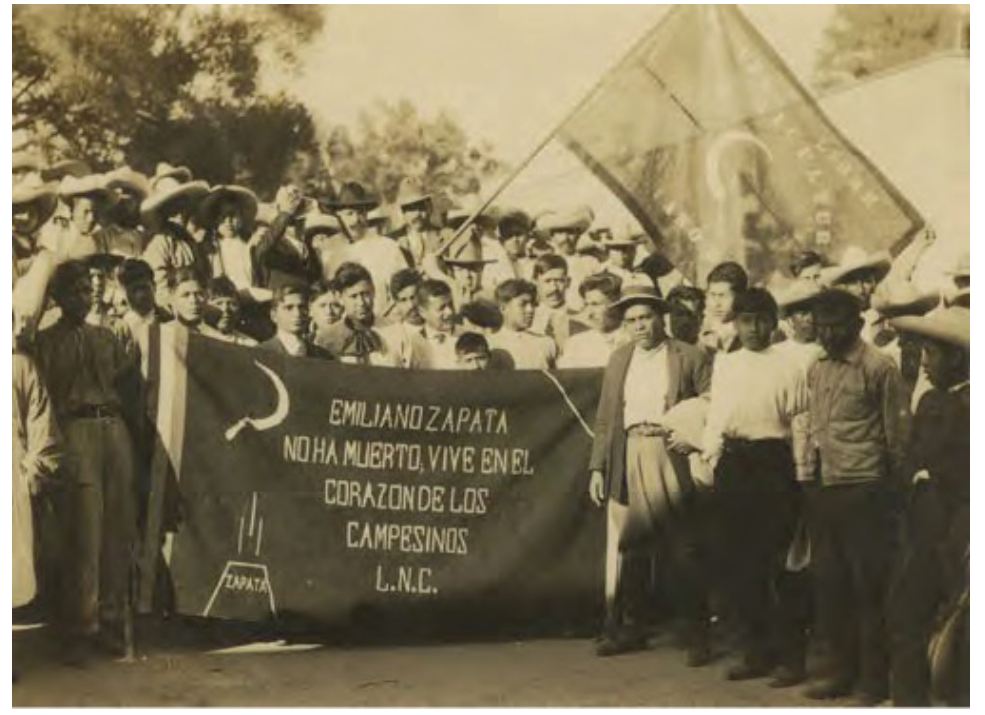

Fonte: Biblioteca Nacional de Fotografia - INAH-SINAFO-MEX

Uma fotografia chama a atenção por sua temática que destoa das demais. Trata-se da imagem de uma igreja localizada em Chipiltepec, Estado do México (Figura 11). Nas atas, nenhuma menção é feita a essa igreja. Ela aparece nessa fotografia, e nada mais. $\mathrm{O}$ desgaste da arquitetura da igreja, o gramado não cuidado e a presença da carroça nos permitem dizer que se trata de um prédio abandonado, naquele contexto. Tina fotografou várias vezes esse tipo de construção, inclusive mosteiros desativados.

Vale lembrar, também, que Tina produziu fotografias sobre arquitetura mexicana para a revista Mexican Folkways ${ }^{34}$, em 1926, um ano antes de começar a trabalhar nesse projeto das escolas agrícolas. Nesse mesmo ano, Tina começou a fotografar murais.

\footnotetext{
33 Tradução livre. No original: "Emiliano Zapata no ha muerto, vive en el corazon de los campesinos".

${ }^{34}$ Mexican Folkways foi um dos principais periódicos produzidos no México nas décadas de 1920 e 1930. Trata-se de uma revista de arte que visou projetar a cultura mexicana para o povo mexicano e para o exterior. A revista foi publicada entre os anos de 1925 e 1937.
} 
A FOTOGRAFIA PARA ALÉM DO REGISTRO HISTÓRICO: O TRABALHO SOCIAL, PEDAGÓGICO E ARTÍSTICO DE Tina Modotti nas "Escuelas Libres de Agricultura"

Fabiane Taís Muzardo

Seu interesse por essa temática, então, não causa estranhamento. O estranho é essa imagem fazer parte da documentação das escolas agrícolas. Ainda que destoe quanto à temática, sua presença serve para reforçar o argumento da preocupação estética de Tina, uma vez que na imagem, em ângulo frontal, se destacam as diferentes formas geométricas da construção, numa estética que, inclusive, se assemelha com as primeiras fotografias de Tina, as quais pesquisadores costumam chamar de "fotografias artísticas".

Figura 11: Tina Modotti, 1928, Fototeca Nacional,10,2 x 12,7 cm

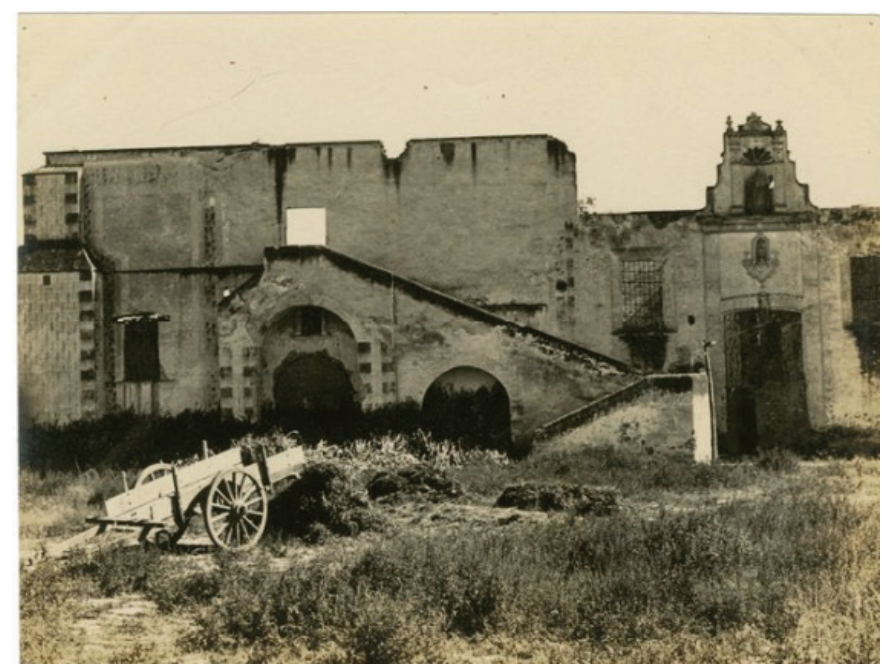

Fonte: Biblioteca Nacional de Fotografia - INAH-SINAFO-MEX

O fato de Tina ter fotografado uma igreja em um contexto em que não há menção a aspectos religiosos pode ser analisado, também, a partir da ideia de nachleben. Durante o trabalho de fotografar atividades agrícolas desenvolvidas por camponeses, Tina escolheu fotografar uma igreja desativada. Trata-se da única imagem sem a presença de pessoas. Essa escolha tem uma carga simbólica. Tina parece nos dizer que os camponeses e camponesas mexicanos resistiram à tentativa de imposição cultural da colonização espanhola, ao mesmo tempo em que foram afetados por ela. Desse processo surgiu a cultura mestiça mexicana, "nascida da interpretação e da conjugação dos contrários"35 (GRUZINSKI, 2007, p. 52).

O México dos anos 1920 caracterizava-se pela efervescência e potência cultural. O projeto de alfabetização, a escola de pintura mural, as escolas agrícolas, todas marcadas por uma produção coletiva, confirmam a importância e valorização que a arte tinha naquele contexto. Esse modo de se pensar e sentir a arte, como potência de transformação social, refuta, mais uma vez, a leitura em fases da produção fotográfica de Tina, pois não é possível pensar, nessa perspectiva, em uma divisão entre o que é artístico e o que é politizado. Tina

35 Tradução livre. No original: "nacida de la interpretación y de la conjugación de los contrários". 
A FOTOGRAFIA PARA ALÉM DO REgISTRO HISTÓRICO: O TRABALHO SOCIAL, PEDAGÓGICO E ARTÍSTICO DE Tina Modotti nas "Escuelas Libres de Agricultura"

Fabiane Taís Muzardo

via a fotografia como um instrumento de luta política. Aqui, "política" foi entendida como um "regime de partilha do espaço e do tempo" (MONDZAIN, 2015, p. 325), que envolve diferentes sujeitos desejantes e detentores de fala. Política, portanto, entendida como relação, como "en el espacio-que-está-entre los hombres" (DIDI-HUBERMAN, 2014, p. 23).

Gruzinski (2006, p. 296) denomina de "edificação revolucionária da população" o trabalho mural desenvolvido pelos artistas mexicanos. $\mathrm{O}$ sentido de arte enquanto possibilidade de transformação social se torna evidente. A própria produçáo cultural coletiva: os pintores que trabalhavam juntos nos murais, as fotografias de Tina que entrelaçavam os aspectos arquitetônicos aos murais, algumas vezes, inclusive, contando com sugestôes de Brenner; a produção de imagens das açôes realizadas pelos camponeses nas escolas agrícolas e o fato de fotografias serem a premiação de eventos realizados nessas escolas; tudo isso ressalta esse caráter de arte enquanto política e luta.

Para além do registro histórico, o trabalho de Tina nas escolas agrícolas indica um ativismo político, pedagógico e estético: as escolhas de composição, o enquadramento, a individualidade/coletividade possível de ser identificada em sua fotografia, colaboraram para a produção de uma memória, marcada pela resistência.

\section{Referências}

BRENNER, Anita. Idolos tras los altares. México: Domés, 1983.

DE DIENHEIM BARRIGUETE, Cuauhtémoc. El artículo 33 de la Constituición y la expulsión de personas extranjeras. Instituto de Investigaciones Jurídicas: Suprema Corte de Justicia de la Nación, 2013.

DIDI-HUBERMAN, Georges. Pueblos expuestos, pueblos figurantes. Ciudad Autónoma de Buenos Aires: Manantial, 2014.

DIDI-HUBERMAN, Georges. Que emoção! Que emoção? São Paulo: Editora 34, 2016.

DUQUE, Isabel Arline. Pandurang Khankhoje, el 'sabio hindú', en México. Alquimia, México DF, n. 50, 2014.

GRUZINSKI, Serge. El pensamiento mestizo. Cultura amerindia y civilización del Renacimiento. Barcelona: Bolsillo, 2007.

GRUZINSKI, Serge. A guerra das imagens: de Cristóvão Colombo a Blade Runner (14922019). São Paulo: Companhia das Letras, 2006.

GUERREIRO, Antonio. As imagens sem memória e a esterilização da cultura. 2012. Disponível em:

http://www.porta33.com/eventos/content_eventos/Antonio_Guerreiro_Aby_Warburg/ Seminario_Antonio_Guerreiro.html. Acesso em: 4 jun. 2019. 
A FOTOGRAFIA PARA ALÉM DO REgISTRO HISTÓRICO: O TRABALHO SOCIAL, PEDAGÓGICO E ARTÍSTICO DE Tina Modotti nas "Escuelas Libres de Agricultura”

Fabiane Taís Muzardo

HOOKS, Margaret. Tina Modotti. Fotógrafa e revolucionária. Rio de Janeiro: José Olympio, 1997.

KAMINSKI, Rosane. Modernidade e identidade: da nação ao mundo. CEFET/PR, nov. 2001.

KAMINSKI, Rosane. Yndio do Brasil, de Sylvio Back: histórias de imagens, história com imagens. In: MORETIN, E; NAPOLITANO, M; KORNIS, M. História e documentário. Rio de Janeiro: FGV, 2012. p. 179-210.

LEÓN, Artemio Cruz; DUQUE, Isabel Arline; CASTRO, Marcelino Ramírez. La investigación agrícola al momento del traslado de la Escuela Nacional de Agricultura de San Jacinto, D.F., a Chapingo, Estado de México, a través de las publicaciones de Pandurang Khankhoje. Revista de Geografía Agricola [en linea] 2015, (Enero-Junio). Disponível em: http://www.redalyc.org/articulo.oa?id=75749285005. Acesso em: 4 jun. 2019.

MACHADO, Arlindo. A ilusão especular. Uma teoria da fotografia. São Paulo: Gustavo Gili, 2015.

MARÍN, Juan Carlos Valdez. Travesía a la imagen en cincuenta números. Alquimia, México DF, n. 50, 2014.

MASSÉ, Patricia. Tina Modotti y el agrarismo radical en México. Alquimia, México DF, n. 50, 2014.

MODOTTI, Tina. Sobre la fotografia. Mexican Folkways, n. 4, 1929.

PRAMPOLINI, Ida Rodríguez (coord.). Muralismo mexicano 1920-1940. Crónicas. México: FCE, Universidad Veracruzana, UNAM, INBA, 2012.

SABORIT, Antonio. Tina Modotti. Una mujer sin pais Las cartas a Edward Weston y otros papeles personales. México: Cal y Arena, 2001.

SONTAG, Susan. Diante da dor dos outros. São Paulo: Companhia das Letras, 2003.

XAVIER, Ismail. Progresso, disciplina fabril e descontração operária. Retóricas do documentário brasileiro silencioso. ArtCultura, Uberlândia, v. 11, n. 18, p. 9-24, jan.-jun. 2009.

\section{Documentos}

ACERVO da Fototeca Nacional. Ata das "Escuelas Libres de Agricultura" de México. El Machete, 25 de agosto de 1928, p. 4. 
A FOTOGRAFIA PARA ALÉM DO REgISTRO HISTÓRICO: O TRABALHO SOCIAL, PEDAGÓGICO E ARTÍSTICO DE Tina Modotti nas "Escuelas Libres de Agricultura"

Fabiane Taís Muzardo

\section{Imagens}

Figura 1: Tina Modotti, 1928, Fototeca Nacional, 7x10 cm. Biblioteca Nacional de Fotografia - INAH-SINAFO-MEX. Disponível em: http://desarrollo-mediateca.inah.gob. $\mathrm{mx} /$ islandora_74/islandora/object/fotografia\%3A468935.

Figura 2: Tina Modotti, 1928, Fototeca Nacional. Biblioteca Nacional de Fotografia - INAHSINAFO-MEX. Disponível em: http://desarrollo-mediateca.inah.gob.mx/islandora_74/ islandora/object/articulo\%3A8600.

Figura 3: Tina Modotti, 1928, Fototeca Nacional, 10,2 x 12,7 cm. Biblioteca Nacional de Fotografia - INAH-SINAFO-MEX. Disponível em: http://desarrollo-mediateca.inah.gob. $\mathrm{mx} /$ islandora_74/islandora/object/fotografia\%3A468943.

Figura 4: Tina Modotti, 1928, Fototeca Nacional, 6,5 x $10 \mathrm{~cm}$ e 10,2 x 12,7 cm. Biblioteca Nacional de Fotografia - INAH-SINAFO-MEX. Disponíveis em: http://desarrollomediateca.inah.gob.mx/islandora_74/islandora/object/fotografia\%3A468929 e http:// desarrollo-mediateca.inah.gob.mx/islandora_74/islandora/object/fotografia\%3A468945.

Figura 5: Tina Modotti, 1928, Fototeca Nacional, 10,2 x 12,7 cm. Biblioteca Nacional de Fotografia - INAH-SINAFO-MEX. Disponíveis em: http://desarrollo-mediateca.inah.gob. $\mathrm{mx} /$ islandora_74/islandora/object/fotografia\%3A53602, http://desarrollo-mediateca.inah. gob.mx/islandora_74/islandora/object/fotografia\%3A468951, http://desarrollo-mediateca. inah.gob.mx/islandora_74/islandora/object/fotografia:53603 e http://desarrollo-mediateca. inah.gob.mx/islandora_74/islandora/object/fotografia\%3A468952.

Figura 6: Tina Modotti, 1928, Fototeca Nacional, 10,2 x 12,7 cm. Biblioteca Nacional de Fotografia - INAH-SINAFO-MEX. Disponíveis em: http://desarrollo-mediateca.inah. gob.mx/islandora_74/islandora/object/fotografia\%3A468930, http://desarrollo-mediateca. inah.gob.mx/islandora_74/islandora/object/articulo\%3A8600 e http://desarrollomediateca.inah.gob.mx/islandora_74/islandora/object/fotografia\%3A468940.

Figura 7: Tina Modotti, 1928, Fototeca Nacional, 10,2 x 12,7 cm. Biblioteca Nacional de Fotografia - INAH-SINAFO-MEX. Disponível em:

http://desarrollo-mediateca.inah.gob.mx/islandora_74/islandora/object/ fotografia\%3A468932.

Figura 8: Tina Modotti. 1928. Biblioteca Nacional de Fotografia - INAH-SINAFO-MEX. El Machete, 25 de agosto de 1928, p. 4. Disponíveis em:

http://desarrollo-mediateca.inah.gob.mx/islandora_74/islandora/object/ fotografia\%3A468941.

Figura 9: Tina Modotti, 1928, Fototeca Nacional, 10,2 x 12,7 cm. Biblioteca Nacional de Fotografia - INAH-SINAFO-MEX. Disponíveis em: http://desarrollo-mediateca.inah.gob. 
A FOTOGRAFIA PARA ALÉM DO REGISTRO HISTÓRICO: O TRABALHO SOCIAL, PEDAGÓGICO E ARTÍSTICO DE Tina Modotti nas "Escuelas Libres de Agricultura”

Fabiane Taís Muzardo

mx/islandora_74/islandora/object/fotografia:468948 e

http://desarrollo-mediateca.inah.gob.mx/islandora_74/islandora/object/ fotografia\%3A468944.

Figura 10: Tina Modotti, 1928, Fototeca Nacional, 10,2 x 12,7 cm. Biblioteca Nacional de Fotografia - INAH-SINAFO-MEX. Disponível em: http://desarrollo-mediateca.inah.gob. $\mathrm{mx} /$ islandora_74/islandora/object/fotografia\%3A468922. 